\title{
High prevalence of HCV coinfection in HIV-infected individuals in Shiraz, Islamic Republic of Iran
}

A. Alipour, ${ }^{7}$ A. Rezaianzadeh, ${ }^{7}$ J. Hasanzadeh, ${ }^{1}$ A. Rajaeefard, ${ }^{1}$ M.A. Davarpanah ${ }^{2}$ and M. Hasanabadi ${ }^{3}$

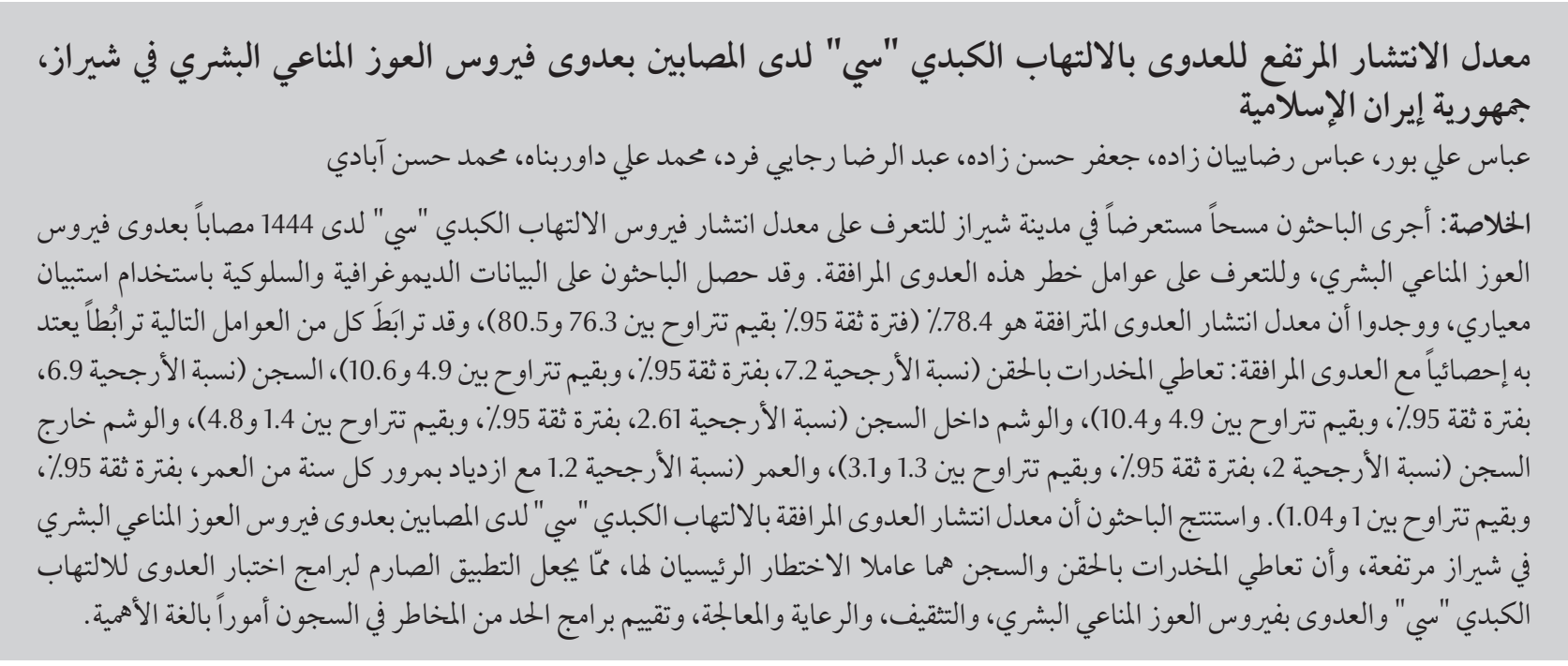

ABSTRACT We carried out a cross-sectional survey in Shiraz to determine the prevalence of hepatitis C virus (HCV) in 1444 individuals infected with human immunodeficiency virus (HIV). We also determined the risk factors for this coinfection. Demographic and behavioural data were obtained using a standard questionnaire. The prevalence of HIV-HCV coinfection was 78.4\% (95\% Cl: 76.3-80.5). Intravenous drug use (OR=7.2; 95\% Cl: 4.9-10.6), imprisonment $(\mathrm{OR}=6.9 ; 95 \% \mathrm{Cl}: 4.6-10.4)$, tattooing in prison $(\mathrm{OR}=2.61 ; 95 \% \mathrm{Cl}: 1.4-4.8)$, tattooing out of prison $(\mathrm{OR}=2.0 ; 95 \% \mathrm{Cl}$ : 1.3-3.1) and age ( $\mathrm{OR}=1.02$ with increasing each year of life; $95 \% \mathrm{Cl}: 1.0-1.04)$ were significantly associated with HCV-HIV coinfection. Prevalence of HCV-HIV coinfection is high in Shiraz. Intravenous drug use and imprisonment are the main risk factors for this coinfection. Therefore, serious implementation of HIV and HCV testing, education, prevention, care and treatment programmes and evaluation of harm reduction programmes in prisons are very important.

Forte prévalence de la co-infection par le virus de l'hépatite $\mathrm{C}$ chez des personnes infectées par le VIH à Chiraz (République islamique d'Iran)

RÉSUMÉ Nous avons mené une enquête transversale à Chiraz afin de déterminer la prévalence du virus de I'hépatite C chez 1444 personnes infectées par le virus de l'immunodéficience humaine (VIH). Nous avons également défini les facteurs de risque de cette co-infection. Les données démographiques et comportementales ont été obtenues à l'aide d'un questionnaire standard. La prévalence de la co-infection par le VIH et le virus de I'hépatite C était de 78,4\% (IC à $95 \%: 76,3-80,5)$. La consommation de drogues injectables (OR = 7,2; IC à 95\% : 4,9-10,6), I'incarcération ( $O R=6,9$; IC à $95 \%: 4,6-10,4)$, un tatouage fait en prison $(O R=2,61$; IC à $95 \%$ : $1,4-4,8)$, un tatouage réalisé hors de prison $(O R=2,0 ;$ IC à $95 \%: 1,3-3,1)$ et l'âge $(O R=1,02$, le risque s'élevant à chaque année de vie supplémentaire ; IC à $95 \%$ : 1,0-1,04) étaient des facteurs fortement associés à une coinfection par le virus de I'hépatite C et le VIH. La prévalence de la co-infection par le virus de l'hépatite C et le VIH est élevée à Chiraz. La consommation de drogues injectables et l'incarcération sont les principaux facteurs de risque de cette co-infection. Par conséquent, la mise en ouvre rigoureuse de programmes de dépistage, d'éducation, de prévention, de soins et de traitement du virus de l'hépatite C et du VIH est très importante, tout comme l'évaluation des programmes de réduction des risques dans les prisons. 


\section{Introduction}

Human immunodeficiency virus (HIV) and hepatitis C virus (HCV) infections are major public health concerns. Because of the similar routes of transmission for both, HIV-HCV coinfection is common [1].

$\mathrm{HCV}$ infection is considered an important cofactor in immunological and clinical progress and treatment results of HIV-infected individuals [2]. Compared to those who are only infected with HIV, coinfected individuals are at greater risk of hepatic toxicity following treatment with antiviral drugs, and their survival is also much lower. A study in India showed that one-third of deaths in HIV infection are directly or indirectly related to HCV infection [3]. Moreover, this coinfection leads to a decline in $\mathrm{HCV}$ clearance and a marked increase in complications of HCV infection [4]. Cellular immunity response to $\mathrm{HCV}$ infection is impaired, and liver fibrosis is also accelerated by HIV infection [5].

It is estimated that worldwide 34.038.6 million individuals are infected with HIV, 170-200 million with HCV and 4-5 million with both HIV and $\mathrm{HCV}[6,7]$. It has been reported that between 68000 and 110000 persons (86000 on average) are infected with HIV in the Islamic Republic of Iran (less than $0.2 \%$ ) [8,9], and less than $1 \%$ are infected with HCV [10]. There is, however, no exact estimate of HIV and HCV coinfection [9]. The prevalence of $\mathrm{HCV}$ infection is lower than in nearby countries, therefore epidemiology of $\mathrm{HCV}$ is affected by factors such as geographical situation, migration between the Islamic Republic of Iran and nearby countries, in particular Afghanistan and Pakistan [11]. In Afghanistan, restrictions (during the long war) on access to heroin pushed up the numbers of injection drug users (IDUs). IDUs are known to be mobile, with almost $80 \%$ reporting that they had changed their residence at least once. Almost 70\% of Mazār-i-Sharif IDUs and 80\% of those in Jalalabad had lived outside Afghani$\operatorname{stan}[12]$.

According to the risk factors, prevalence of HIV and HCV coinfection varies in different countries and even in different parts of a country [13]. Prevalence of HCV infection among HIVinfected individuals, based on serologic tests, has been reported to be $49 \%$ in Italy, $70 \%$ in Ukraine, 54\% in Brazil, and $25 \%-40 \%$ in the United States of America and unofficial reports from the Islamic Republic of Iran reported between $8.7 \%$ and about $90 \%$ in prison intravenous (IV) drug users [14-16].

Coinfection of HCV and HIV can be affected by factors like use of IV drugs, geographical area, frequency of each infection in the area, tattooing, body piercing, and common use of blades, injection and tattooing instruments, sexual contact, imprisonment, age and marital status. However, based on the reported studies there is only high agreement regarding exposure to infected blood (such as use of IV drugs) as an influencing factor [17-19].

To our knowledge, so far there have been a very limited number of studies on prevalence of HCV in HIV-infected individuals in the Islamic Republic of Iran and in particular in Shiraz (centre of Fars province), which is a referral centre for HIV patients from the southern part of the country.

Therefore, the aim of this study was to evaluate the prevalence of $\mathrm{HCV}$ in HIV-infected individuals and the risk factors of this coinfection in Shiraz.

\section{Methods}

This study was conducted at the Shiraz Counselling Centre for Behavioural Diseases. By July 2011, 1683 HIVpositive individuals had attended the centre. For this study, we reviewed the records of all HIV-infected persons who had been diagnosed with a newly acquired HCV infection from April 2003 to July 2011. These patients were confirmed HIV-infected individuals (serial enzyme-linked immunosorbent assay and Western blot tests) identified among thousands of individuals referred to this centre owing to their risky behaviours. In the centre, HIV-infected patients receive some free services every 9 months such as regular laboratory and radiological examinations or medications prescribed by a physician, and personal and family consultation. Additional consultations were possible at any time between routine visits for any health problem. Patients with a negative HCV serological result at the initial HIV consultation were re-tested if there was a subsequent increase in the level of liver aminotransferases or high risk behaviours. All participants included in the study had given informed written consent.

Criteria for inclusion in the survey were being visited twice by the infectious disease specialist in the previous 18 months and being over 17 years old. Accordingly, 1444 patients were eligible to participate in the study. A nationally available, standard questionnaire, designed by the Centre for Disease Control in the Iranian Ministry of Health, was completed for all patients included in the study. Questions covered demographic data (age, sex, race, residency area, and education level) and data regarding history of blood transfusion before 1996 (when donated blood was not checked for HCV infection in the Islamic Republic of Iran [20]); history of tattooing; history of common use of blades, injection and tattooing instruments; sexual behaviours; and injection drug use. Data related to HIV infection such as number of CD4s (cluster of differentiation 4, previously leu-3 or T4), antiviral drug use, estimated duration of HIV infection, and other opportunistic infections such as tuberculosis were also included. The interviewers were 4 nurses from the centre 2 men and 2 women. They were well-trained and at the same time familiar with the patients under study. The quality control of the 
data collected was carried out by the researchers from March to July 2011. This involved rechecking the records of all eligible patients for missing data and in case of missing data rechecking laboratory or risk factor records; if data were still incomplete, re-interview was the done wherever possible.

A venous sample from the arm was taken by a professional phlebotomist from all patients. Using enzyme-linked immunosorbent assay (ELISA), the samples were screened for anti-HIV antibodies (Delaware Biotech Inc., United States of America) and then by western blot (MP Diagnostics, Germany) the diagnosis of HIV was confirmed. A third generation ELISA test (Dia.Pro, Italy) was used for determination of anti-HCV Ab. A positive result from both the western blot (for HIV result) and the third generation ELISA test (for HCV result) was deemed HIV-HCV coinfection.

CD4+ cell counts were measured using flow cytometry (Partec, Germany).

For estimation of prevalence of coinfection, point prevalence with $95 \%$ confidence interval in each subgroup was calculated. The total number of positive results divided by total number of positive and negative results was considered point prevalence. Unknown results for each infection were not taken into account in the denominator. For the calculation of confidence intervals, Wald statistics were used [21].

To evaluate the association between HCV infection and explanatory factors in univariate analysis, the chi-squared test was used and in multivariate analysis the binary logistic regression test. A complete model including injection drug use and other variables was constructed. Then this model was reduced to the final model by hierarchical backward elimination [22]. Because IDU was the main exposure variable, we retained it in all further models.
The significance level for univariate analyses was 0.05 . All statistical analyses were performed using Stata, version 10.

\section{Results}

A total of 1444 HIV patients were evaluated for HCV infection and its related factors. Mean age was 38.4 (standard deviation 9.2) years. The majority of our patients were males (85.2\%); $61.5 \% \%$ were aged $\geq 35$ years, and $76.0 \%$ were residents of Shiraz (Table 1).

The overall prevalence of HIVHCV coinfection was 78.4\% (95\% CI: 76.3-80.5). Prevalence of coinfection in relation to demographic characteristics is shown in Table 1. Older age, male sex, low education level, single status, residence in Shiraz, working as a driver or being self employed were significantly associated with presence of coinfection.

The relationship between coinfection and behavioural characteristics is shown in Table 2. Imprisonment, IV drug use, extra-marital sexual contact, blood donation and transfusion, sexually transmitted infection, tattooing and the use of a common razor (both inside and outside of prison) were significantly associated with the presence of coinfection.

In the binary logistic regression model, IV drug use, imprisonment, tattooing and age were potential predictors of HCV infection in HIV-infected individuals (Table 3). The risk of having coinfection for IV drug users was 7.2 (95\% CI: 4.9-10.6) times higher and for imprisonment it was 6.9 (95\% CI: 4.6-10.4) times higher.

None of the variables of binary interaction remained in the model.

\section{Discussion}

Our study showed that the prevalence of HCV-HIV coinfection was high (78.4\%) and age, IV drug use, and tattooing inside and outside prison were independently associated with a higher risk of coinfection.

Other studies have shown that the prevalence of this coinfection varies worldwide and it is related to geographical area, high risk groups and type of exposure. Amin et al. in the CAESAR (Canada, Australia, Europe, and South Africa) study reported that the prevalence of this coinfection varies from $1.9 \%$ in South Africa to $48.6 \%$ in Italy, and the overall prevalence was $16.1 \%$ [23]. In general, it could be expected that $25 \%$ of all HIV-infected persons would be coinfected with HCV $[24,25]$. $\mathrm{HCV}$ is transmitted primarily through large or repeated percutaneous (i.e. passage through the skin) exposure to infected blood, such as with IV drug use. It seems that the prevalence of IV drug use in the population studied is a major reason for differences in the prevalence of HCV-HIV coinfection [26]. In general in populations where HIV is mainly transmitted by IV drug use and blood transfusion, the prevalence of HCV-HIV coinfection can go up to $75 \%$ [25]. Since in the Islamic Republic of Iran HIV is transmitted in 70\%-76\% of cases by the intravenous route [9], then a high prevalence is expected for this coinfection [16]. As risk reduction programmes have been established by the government since 2007 [14], a lower prevalence of this coinfection is expected in future.

Common use of needles and syringes is responsible for the spread of $\mathrm{HCV}$ infection in populations with a high prevalence of this infection [10]. Dropin centres are found in poor urban areas and provide reliable information and education around drug use and the risks of HIV infection, as well as access to clean needles, condoms and general healthcare for intravenous drug users and other high risk groups.

Our study shows that HCV-HIV coinfection is more prevalent in older age groups. It is likely that this is a result of the build up of the coinfected individuals over time [2] and increase 


\begin{tabular}{|c|c|c|c|c|c|}
\hline \multirow[t]{2}{*}{ Characteristic } & \multicolumn{2}{|c|}{ HIV-infected } & \multirow{2}{*}{$\begin{array}{l}\text { HIV-HCV coinfection } \\
\text { No. }\end{array}$} & \multirow{2}{*}{$\begin{array}{c}\text { Coinfection prevalence } \\
\%(95 \% \mathrm{CI})\end{array}$} & \multirow[t]{2}{*}{$P$-value ${ }^{a}$} \\
\hline & No. & $\%$ & & & \\
\hline Total & 1444 & 100.0 & 1132 & $78.4(76.3-80.5)$ & \\
\hline \multicolumn{6}{|l|}{ Sex } \\
\hline Male & 1230 & 85.2 & 1095 & $89.1(87.3-90.8)$ & \multirow{2}{*}{$<0.0001$} \\
\hline Female & 215 & 14.9 & 38 & $17.7(12.6-22.8)$ & \\
\hline \multicolumn{6}{|l|}{ Age (years) } \\
\hline $17-24$ & 46 & 3.2 & 23 & $50.0(35.5-64.4)$ & \multirow{3}{*}{$<0.0001$} \\
\hline $25-34$ & 510 & 35.3 & 384 & $75.3(71.6-79.1)$ & \\
\hline$\geq 35$ & 888 & 61.5 & 725 & $81.64(79.1-84.2)$ & \\
\hline \multicolumn{6}{|l|}{ Education } \\
\hline $\begin{array}{l}\text { Illiterate \& primary } \\
\text { school }\end{array}$ & 544 & 37.8 & 423 & $77.8(74.3-81.3)$ & \multirow{3}{*}{$<0.0001$} \\
\hline $\begin{array}{l}\text { Did not complete high } \\
\text { school }\end{array}$ & 863 & 60.0 & 691 & $80.1(77.4-82.7)$ & \\
\hline $\begin{array}{l}\text { Completed high school } \\
\text { or above }\end{array}$ & 32 & 2.2 & 16 & $50.0(32.7-67.3)$ & \\
\hline \multicolumn{6}{|l|}{ Marital status } \\
\hline Single & 537 & 37.4 & 474 & $88.3(85.5-9)$ & \multirow{4}{*}{$<0.0001$} \\
\hline Married & 532 & 37.0 & 371 & $69.7(65.8-73.6)$ & \\
\hline Divorce & 73 & 5.1 & 26 & $35.6(24.6-46.6)$ & \\
\hline Widow & 295 & 20.5 & 259 & 87.8 (84.1-91.5) & \\
\hline \multicolumn{6}{|l|}{ Residence } \\
\hline Shiraz & 1097 & 76.0 & 889 & $81.1(78.7-83.4)$ & \multirow{2}{*}{$<0.0001$} \\
\hline Other & 346 & 24.0 & 242 & $69.9(65.1-74.8)$ & \\
\hline \multicolumn{6}{|l|}{ Occupation } \\
\hline Employee & 24 & 1.7 & 11 & $45.8(25.9-65.8)$ & \multirow{7}{*}{$<0.0001$} \\
\hline Self-employed & 562 & 39.1 & 501 & $89.2(86.6-91.7)$ & \\
\hline Agriculturist & 22 & 1.5 & 18 & 81.8 (59.7-94.8) & \\
\hline Unemployed & 587 & 40.8 & 464 & 79.1 (75.7-97.9) & \\
\hline Home worker & 122 & 8.5 & 29 & $23.8(16.2-31.3)$ & \\
\hline Student & 6 & 0.4 & 2 & $33.3(0.0-71.7)$ & \\
\hline Driver & 116 & 8.1 & 105 & $90.5(85.2-95.8)$ & \\
\hline
\end{tabular}

${ }^{a}$ Chi-squared test.

$H I V=$ human immunodeficiency virus; $H C V=$ hepatitis $C$ virus; $C I=$ confidence interval.

in duration of exposure to risky behaviours. The lower prevalence in younger age groups could be a result of the risk reduction programmes in the Islamic Republic of Iran. Further studies are needed for the effectiveness of these programmes to be determined. The same association between age and coinfection has been shown in other parts of Iran [2].

Imprisonment also has a major role in transmission of HCV. Prison is a place in which use of infected syringes is common and prevalence of HIV and $\mathrm{HCV}$ is also high. Since use of narcotics by inhalation is difficult in prison some of addicts may become injection drug users [27]. Therefore, prison is an important risk factor in HCV transmission. Duration of imprisonment is also directly associated with risk of $\mathrm{HCV}$ transmission [16].

Tattooing is an activity that takes place secretively, often in unhygienic environments, using homemade equipment and inks. Tattooing may provide a link between non-injecting and injecting prisoners, thus enabling blood-borne infections to be disseminated. This risk factor is a known way for HCV transmission. Conversely, the finding of some other studies didn't indicate this association. This discrepancy could be explained, at least in part, by difference in the area and number of tattooing point [28]. Risk of HCV transmission via tattooing is depended to the HCV prevalence in the population and studies have shown 


\begin{tabular}{|c|c|c|c|c|c|}
\hline \multirow[t]{2}{*}{ Characteristic } & \multicolumn{2}{|c|}{ HIV-infected } & \multicolumn{2}{|c|}{ HCV-HIV coinfection } & \multirow[t]{2}{*}{$P$-value ${ }^{\text {a }}$} \\
\hline & No. & $\%$ & No. & $\%(95 \% \mathrm{Cl})$ & \\
\hline Total & 1444 & & 1132 & $78.4(76.3-80.5)$ & \\
\hline Imprisonment & 1111 & 76.9 & 1031 & $92.8(91.3-94.3)$ & $<0.0001$ \\
\hline Intravenous drug use & 1070 & 74.1 & 997 & $93.2(91.7-94.7)$ & $<0.0001$ \\
\hline Extramarital sexual contact & 676 & 46.8 & 591 & $87.4(84.9-89.9)$ & $<0.0001$ \\
\hline Blood transfusion & 157 & 10.9 & 134 & $85.5(79.8-90.9)$ & 0.025 \\
\hline Blood donation & 245 & 17.0 & 210 & $85.7(81.3-90.1)$ & 0.002 \\
\hline Sexually transmitted infection & 105 & 7.3 & 91 & $86.7(80.2-93.2)$ & 0.032 \\
\hline Tattooing outside prison & 445 & 30.8 & 403 & $90.6(87.8-93.3)$ & $<0.0001$ \\
\hline Tattooing in prison & 352 & 24.4 & 337 & $95.7(93.6-97.8)$ & $<0.0001$ \\
\hline Sharing a razor outside prison & 58 & 4.0 & 53 & $91.4(84.2-98.6)$ & 0.014 \\
\hline Sharing a razor in prison & 437 & 30.2 & 407 & $93.1(90.8-95.5)$ & $<0.0001$ \\
\hline CD4 $<200$ & 320 & 34.9 & 256 & $80.0(75.6-84.4)$ & \multirow{2}{*}{0.001} \\
\hline $\mathrm{CD} 4 \geq 200$ & 598 & 65.1 & 417 & $69.7(66.1-73.4)$ & \\
\hline
\end{tabular}

${ }^{a}$ Chi-squared test.

$H C V=$ hepatitis $C$ virus; HIV = human immunodeficiency virus; $C I=$ confidence interval .

that this risk is much higher in prisoners $[16,28]$.

Programmes like increasing awareness; education, particularly through peers; provision of condoms and other measures for reducing sexual transmission; needles, syringes and sterile equipment for tattooing programmes; drug dependence treatment, in particular opioid substitution therapy; voluntary counselling and HIV testing; and HIV care, treatment and support, including provision of antiretroviral treatment are important actions that should be carried out [29]. Harm-reduction programmes such as needle, syringe and sterile equipment exchange have been associated with reductions in HIV and $\mathrm{HCV}$ incidence.
There were some limitations for this study. The exact time of HCV and HIV infection and their sequence was not clear. Thus it is not clear which infection is a predisposing factor for the other.

Because HCV is more transmissible than HIV (parenteral transmission of $\mathrm{HCV}$ infection is approximately 10 times greater than HIV infection [30]) and a majority of our sample were IDUs, it is possible that participants with HIV-HCV coinfection had been infected with HCV before HIV. To determine, this prospective cohort studies would be needed. Another limitation was under reporting of extra marital sexual contacts and homosexuality because of the culture of the country leading to social desirability response bias [2].

\begin{tabular}{lccc}
\hline \multicolumn{4}{l}{ Table 3 Final multivariate logistic regression analysis of risk factors for HCV-HIV } \\
coinfection among HIV-infected individuals, Shiraz, 2011 & \multicolumn{1}{l}{} \\
\hline Variable & Adjusted OR (95\% CI) & SE & P-value \\
Intravenous drug use & $7.2(4.9-10.6)$ & 0.197 & $<0.0001$ \\
Imprisonment & $6.9(4.6-10.4)$ & 0.21 & $<0.0001$ \\
Tattooing inside prison & $2.6(1.4-4.8)$ & 0.311 & 0.002 \\
Tattooing outside prison $_{\text {Age }^{\mathrm{a}}}$ & $2.0(1.3-3.1)$ & 0.681 & 0.002 \\
\hline
\end{tabular}

${ }^{a}$ With each year increase in age.

$O R=$ odds ratio; $C l=$ confidence interval; $S E=$ standard error .

Over reporting of $\mathrm{HCV}$ is also probable, because HCV RNA was not checked with anti-HCV Ab.

Health care services for HIV infection are only based in the public health sector in the Islamic Republic of Iran. Shiraz Centre of Behavioural Consult and Health Presentation is the only centre delivering health services to HIV-infected individuals from the southern part of the country. All HIV patients from any socioeconomic or cultural background from the region are referred to this centre. The sample of this study was chosen from population of HIV patients of the above centre. It can, therefore, be concluded that our sample is representative of HIV patients in this region. However, some people may seek treatment from adjacent provinces.

To reduce information bias, samples before 2005 were not included in this study because the records were not complete or reliable.

Our findings indicate that to decrease the risk of transmission in prison, disposable and clean syringes and needles for IDUs and clean and sterile instruments for tattooing should be available. Moreover, maintenance 
treatment by methadone to change injection addiction to non-injection is necessary. Maintenance treatment reduces high risk behaviours that are associated with HIV and HCV transmission, including sharing of injection equipment, sex work to get money for drugs [31] and rate of future imprisonment [32] (shown in this study to be a risk factor for coinfection).

The importance of our findings is increased when we realise that in the Islamic Republic of Iran per capita consumption of narcotics is high [33], and the number of injection drug users [33], prevalence of HIV and imprisonment [8] among IV drug users is increasing. Therefore without effective interventions we anticipate that the number of HIV-infected and prisoner IV drug users will increase.

\section{Conclusion}

The majority of HIV-infected individuals are coinfected with HCV, and their prognosis and treatment could be affected by this coinfection. Age, injection drug use, imprisonment, and tattooing are important risk factors for HCV transmission in HIV patients. Diagnosis of HIV infection is a good opportunity for the health system to check these patients for HCV infection and to use harm reduction programmes to reduce morbidity and mortality following HCV infection. In prison, IV drug use and tattooing emphasizes the role of prison in HCV transmission. Implementation of harm reduction programmes, HIV and HCV testing, education, prevention, care and treatment programmes are necessary to improve this situation.
Acknowledgements

The authors would like to acknowledge the cooperation of the head of the HIV Research Centre, Dr Hasan Julaeel and his colleagues, the head of the local Centre for Disease Prevention and Control (CDC), Dr Parvin Afsar Kazeroonithe and her colleague Dr Sabet, and colleagues in the Shiraz Counselling Centre for Behavioural Diseases, Ms Mahnaze Novzarian, Mr Mohammad Ali Musavi, Mr Mahdi Shirazi and Mr Rezaee in this study.

Funding: This study was financially supported by the Vice Chancellor for Research Affairs, Shiraz University of Medical Sciences, through contract no. 90-5605.

Competing interests: None declared.

\section{References}

1. Modi A, Feld J. Viral hepatitis and HIV in Africa. AIDS Reviews, 2007, 9:25-39.

2. Hosseini $\mathrm{M}$ et al. Prevalence and correlates of co-infection with human immunodeficiency virus and hepatitis $C$ virus in male injection drug users in Iran. Archives of Iranian Medicine, 2010, 13:318-323.

3. Kumarasamy $\mathrm{N}$ et al. Clinical profile of HIV in India. Indian Journal of Medical Research, 2005, 121:377-394.

4. Schnuriger A et al. Acute hepatitis C in HIV-infected patients: rare spontaneous clearance correlates with weak memory CD4 T-cell responses to hepatitis C virus. AIDS (London, England), 2009, 23:2079-2089.

5. Kim A et al. The magnitude and breadth of hepatitis $C$ virusspecific CD8+ T cells depend on absolute CD4+ T-cell count in individuals coinfected with HIV-1. Blood, 2005, 105:1170-1178.

6. Koziel MJ, Peters MG. Viral hepatitis in HIV infection. New England Journal of Medicine, 2007, 356(14):1445-1454.

7. Van de Laar TJW et al. Acute hepatitis C in HIV-infected men who have sex with men: an emerging sexually transmitted infection. AIDS (London, England), 2010, 24:1799-1812.

8. 2008 Report on the global AIDS epidemic. Geneva, UNAIDS, 2008 (http://www.unaids.org/en/dataanalysis/knowyourepidemic/epidemiologypublications/2008reportonthe globalaidsepidemic/, accessed 24 March 2013).

9. National AIDS Committee. Iran country report on monitoring of the United Nations general assembly special session on HIV and AIDS, declaration of commitment. Tehran, Iranian Ministry of Health, 2008 [in Farsi].

10. Alavian S, Adibi P, Zali M. Hepatitis C virus in Iran: epidemiology of an emerging infection. Archives of Iranian Medicine, 2005, 8:84-90.

11. Alavi S, Hajiani E. Hepatitis C infection: a review on epidemiology and management of occupational exposure in health care workers for general physicians working in Iranian health network setting. Jundishapur Journal of Microbiology, 2011, 4(1):1-9.

12. UNGASS country progress report Afghanistan reporting period: January 2008 to December 2009. Kabul, Afghanistan, Ministry of Public Health, Communicable Disease Directorate (CDC), 2010.

13. Jindal N, Arora U, Singh K. Prevalence of human immunodeficiency virus (HIV), hepatitis B virus, and hepatitis C virus in three groups of populations at high risk of HIV infection in Amritsar (Punjab), Northern India. Japanese Journal of Infectious Diseases, 2008, 61(1):79-81.

14. Rahimi-Movaghar A et al. HIV, hepatitis C virus, and hepatitis B virus co-infections among injecting drug users in Tehran, Iran. International Journal of Infectious Diseases, 2010, 14:28-33.

15. SeyedAlinaghi $S$ et al. Hepatitis-C and hepatitis-B co-infections in patients with human immunodeficiency virus in Tehran, Iran. Acta Medica Iranica, 2011, 49:252-257.

16. MohtashamAmiri $Z$ et al. Prevalence of hepatitis $C$ virus infection and risk factors of drug using prisoners in GuiIan province. Eastern Mediterranean Health Journal, 2007, 13(2):250-256.

17. Bollepalli $S$ et al. Prevalence of risk factors for hepatitis $C$ virus in HIV-infected and HIV/hepatitis C virus-coinfected patients. Sexually Transmitted Diseases. 2007, 34(6):367-370.

18. Ghosn J et al. Increase in hepatitis C virus incidence in HIV1-infected patients followed up since primary infection. Sexually Transmitted Infections. 2006, 82(6):458-460.

19. Wolff $\mathrm{FH}$ et al. Risk factors for hepatitis $\mathrm{C}$ virus infection in individuals infected with the HIV. Digestive and Liver Disease, 2008, 40:460-467.

20. Kafi-abad SA et al. Prevalence and trends of human immunof deficiency virus, hepatitis B virus, and hepatitis C virus among blood donors in Iran, 2004 through 2007. Transfusion, 2009, 49:2214-2220. 
21. Agresti A. An introduction to categorical data analysis, 2nd ed. New Jersey, John Wiley \& Sons Inc., 2007.

22. Kleinbaum DG. Logistic regression: A self-learning text, 2nd ed. New York, Springer-Verlag, 2002.

23. Amin J et al. HIV and hepatitis $\mathrm{C}$ co-infection within the CAESAR study. HIV Medicine, 2004, 5:174-179.

24. Mallet V, Vallet-Pichard A, Pol S. The impact of human immunodeficiency virus on viral hepatitis. Liver International, 2011, 31(Suppl. 1):135-139.

25. Soriano V et al. Viral hepatitis and HIV co-infection. Antiviral Research, 2010, 85(1):303-315.

26. BuxtonJ et al. HCV co-infection in HIV positive population in British Columbia, Canada. BMC Public Health, 2010, 10:225.

27. Zamani $S$ et al. Prevalence of and factors associated with HIV-1 infection among drug users visiting treatment centers in Tehran.Iran. AIDS (London, England), 2005, 19:709-716.
28. Jafari $\mathrm{S}$ et al. Tattooing and the risk of transmission of hepatitis C : a systematic review and meta-analysis. International Journal of Infectious Diseases, 2010, 14:e928-e940.

29. Effectiveness of interventions to address HIV in prisons. Geneva, World Health Organization, 2007.

30. Thomas DL. Hepatitis $C$ and human immunodeficiency virus infection. Hepatology (Baltimore, Md.), 2002, 36(Suppl. 1):S201-S209.

31. Drucker E et al. Measuring harm reduction: the effects of needle and syringe exchange programs and methadone maintenance on the ecology of HIV. Aids, 1998, 12(Suppl. A):S217-S230.

32. Dolan $\mathrm{K}$ et al. HIV risk behaviour of IDUs before, during and after imprisonment in New South Wales. Addiction Research, 1997, 4:151-160

33. Razzaghi $E$ et al. Pro les of risk: a qualitative study of injecting drug users in Tehran, Iran. Harm Reduction Journal, 2006, 3:12. 